\title{
PREDICTION OF INFLOW DIRECTION AT LARGE OPENING OF CROSS VENTILATED APARTMENT BUILDING
}

\author{
集合住宅の大開口に招ける通風気流の流入角予測法 \\ Hisashi KOTANI* and Toshio YAMANAKA** \\ 甲谷寿史，山中俊夫
}

\begin{abstract}
In case of cross ventilation through the large opening, it is well known that the inflow direction at the opening is not normal to the opening. This is one of the reason to cause the error in calculation when the conventional 'orifice equation' is adopted for cross ventilation. In this paper, authors proposed the simplified prediction method of the inflow direction at the inlet opening and the airflow rate simultaneously. The new concept and the core of this method is the prediction of inflow direction at the opening by use of vector composition of the wind velocity parallel to wall and normal to the opening. As the first step of the validation of this method, the prediction accuracy of the inflow direction was investigated. The wind tunnel tests using a three-storied apartment building model with a room were conducted to investigate the inflow direction. The combination of the room positions and the external wind directions make various inflow directions at the inlet opening. The measurement results of inflow direction were compared with the calculated results.
\end{abstract}

Keywords : cross ventilation, prediction, inflow direction, wind tunnel test

通風, 予測法, 流入角, 風洞実験

1. Introduction

Cross ventilation has been studied for long time by many researchers, especially Japanese researchers have been interested in this topic because the cross ventilation is common used in Japan to improve the indoor thermal environment in hot summer season ${ }^{1)-5)}$. Recently the members of IEAECBCS Annex 35 (HybVent) have been conducting energetic researches and many useful results have been obtained as well ${ }^{6-8)}$.

In case of cross ventilation through the large opening, it is well known that the cross ventilation makes a flow contact of windward and leeward openings as shown in Figure 1. In this situation, the use of general discharged coefficient $\left(C_{\mathrm{D}}\right)$ values is not suitable for the calculation of cross ventilation rate. The total pressure loss coefficient of the room $(\xi)$ becomes smaller than the connection of the pressure loss coefficient of an opening in series $\left(\zeta_{1}+\zeta_{2}\right) . C_{\mathrm{D}}$ value is the reciprocal of square root of $\zeta_{1}+\zeta_{2}$, so the calculation by $C_{\mathrm{D}}$ values under-estimates the cross ventilation rate. To deal with this decrease of pressure loss coefficient, Ishihara ${ }^{11}$ proposed 'Interference factor' which is the ratio of $\xi$ to $\Sigma \zeta$.

Secondly, the pressure loss coefficient or $C_{\mathrm{D}}$ value of an opening varies with the inflow direction and the use of normal values over-estimates the airflow rate. Ishihara ${ }^{1)}$ also showed the experimental data and $\xi$ becomes large in case of the larger argument of two openings.
Many researchers are supporting these two tendencies of the pressure loss coefficient ${ }^{1-5)}{ }^{9-13}$. More detailed reviews about this problem are seen in Kurabuchi and Ohba ${ }^{14)}$.

Although there are many researches from the above-mentioned viewpoint, there used to be few researches to develop the simple but reasonable prediction method of the cross ventilation rate. Recently, Kurabuchi et al. ${ }^{10)}$ tried to reveal the mechanism of cross ventilation using CFD and proposed 'Local Dynamic Similarity Model of Cross Ventilation' as the systematic prediction method of flow rate. In this paper, reasonable and systematic prediction method of the cross ventilation rate through large

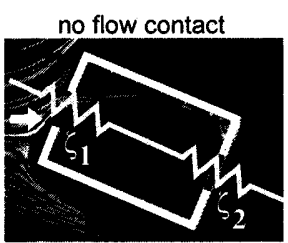

room with small openings

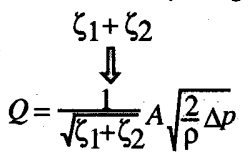

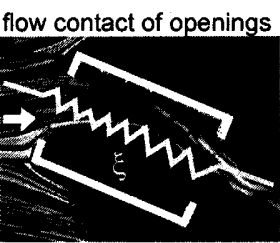

room with large openings $\xi<\zeta_{1}+\zeta_{2}$

$\downarrow$
Fig. 1 Flow contact between two openings and the use of total pressure loss coefficient instead of pressure loss coefficient of an opening.
* Assistant Prof., Division of Global Architecture, Graduate School of Eng., Osaka University, Dr. Eng.

** Assoc. Prof., Division of Global Architecture, Graduate School of Eng., Osaka University, Dr. Eng.
大阪大学大学院工学研究科地球総合工学専攻 講師 · 博士 (工学)

大阪大学大学院工学研究科地球総合工学専攻 助教授・博士 (工学) 
openings was proposed and its experimental validation was carried out. 'Local Dynamic Similarity Model' consists of pressure-based description and tends to be accurate. The proposed method in this paper tends to be easy to understand aiming the practical use. The wind pressure coefficient $(C p)$ as in the ordinary method and the wind velocity parallel to the wall were adopted in this method.

Needless to say, the goal of this research is to propose the prediction method of cross ventilation rate. In the previous researches, authors have studied the total pressure loss coefficient of the room ${ }^{11)}{ }^{12)}$, the prediction of the wind pressure coefficient ${ }^{15)}$ and the wind velocity parallel to the wall for the apartment-shaped building ${ }^{16)}$, so these researches will be integrated with the proposed method in this paper in the near future. In the end, the pressure loss coefficient (or $C_{\mathrm{D}}$ ) or $C \mathrm{p}$ should be changed from the general values, when the conventional 'orifice equation' is used. Authors collected a lot of $C \mathrm{p}$ data for the different shaped buildings and planed to adopt Ishihara's 'Interference factor' for $\xi$ from its easiness to understand. Therefore authors choose the change of the pressure loss coefficient in this paper. Some researchers can choose the change of $C \mathrm{p}$. Authors' standpoint for this research is just the choice from the many approaches to this cross ventilation problem.

This paper shows the effectiveness of the calculation method itself, so the measured values are used for above-mentioned three parameters and only the calculation method of inflow direction are checked. This paper only shows the validation in the case that two openings are arranged in series at the opposite side of the room, as the first step of the validation of this calculation method.

\section{Simultaneous calculation of inflow direction and airflow rate}

As mentioned above, it is well known the pressure loss coefficient or $C_{\mathrm{D}}$ of an opening varies with the inflow direction. Kotani et al. ${ }^{11)}{ }^{12}$ ) have made experiments to know $\xi$ under various opening sizes, room sizes and wind directions. It was found that $\xi$ also varies according to the inlet wind direction. Therefore the authors propose the simultaneous calculation method of inflow direction and airflow rate. Figure 2 shows the procedure of the airflow rate. At first, outdoor wind direction, building shape and room condition (location and dimension) decide the wind pressure coefficient $(C \mathrm{p})$ and the wind velocity parallel to wall $\left(v_{\mathrm{w}}\right)$. Secondly, inflow direction at the opening $(\theta)$ is obtained from $v_{\mathrm{w}}$ and airflow rate $(Q) . \theta$ derive the pressure loss coefficient of room $(\xi)$ by the empirical relation between these two values at the certain condition of opening dimension and room dimension. $Q$ can be calculated by $\xi$ and wind pressure difference $\Delta p$ obtained from $C p$ and outdoor wind velocity. Finally, $Q$ and $\theta$ are calculated by iteration. In this method, following data for different conditions are needed in advance; (1) $C_{\mathrm{p}}$ value, (2) $v_{\mathrm{w}}$ value, (3) relationship between $\theta$ and $\xi$.

The new concept and the core of this method is the prediction of inflow direction at the opening by use of vector composition of the wind velocity parallel to the wall and normal to the opening as shown in Figure 3. The wind velocity parallel to the wall is the velocity in front of the opening, when the opening is closed. It is reasonable to use this velocity when the opening is relatively small compared with the whole building wall.
This needs to be measured, but the authors have already had many measured data for various building shapes ${ }^{16}$. Further research is now planning to prepare the reasonable function of this wind velocity. The wind velocity normal to the opening is the value which is the resultant airflow rate $(Q)$ divided by opening area $(A)$. The initial value of $Q$ is calculated by the simple orifice equation and this value and total pressure loss coefficient of room $\xi$ are calculated simultaneously by iteration. $C p$ values are used in the orifice equation and $C_{\mathrm{p}}$ values should be measured as well, but authors have made a regression function for the various building shapes in the previous research ${ }^{15)}$. Though this calculation needs the iteration, it is not so complicated by the use of simple vector composition. The practical use is intended and the use of the velocities parallel and normal to the wall is easy

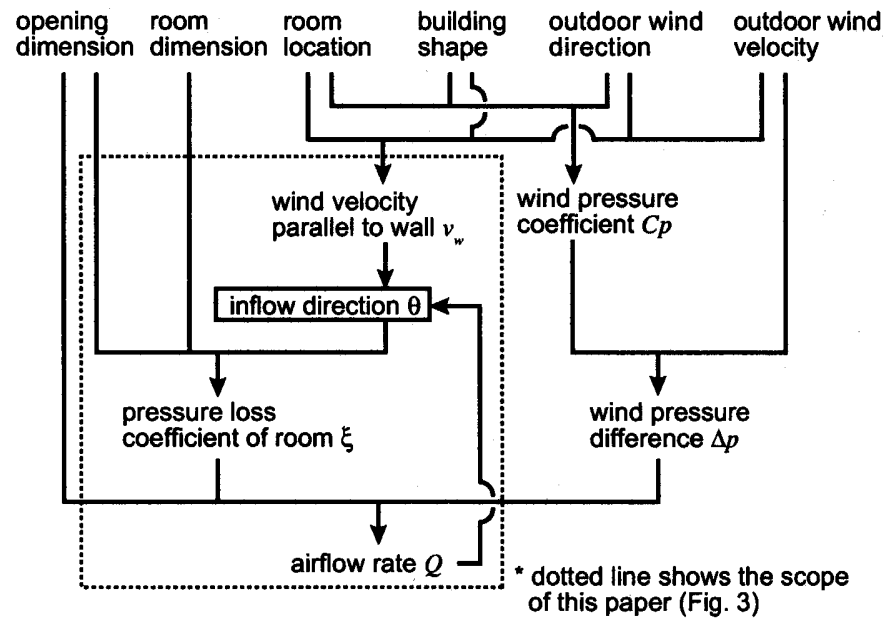

Fig. 2 Simultaneous calculation of inflow direction and airflow rate

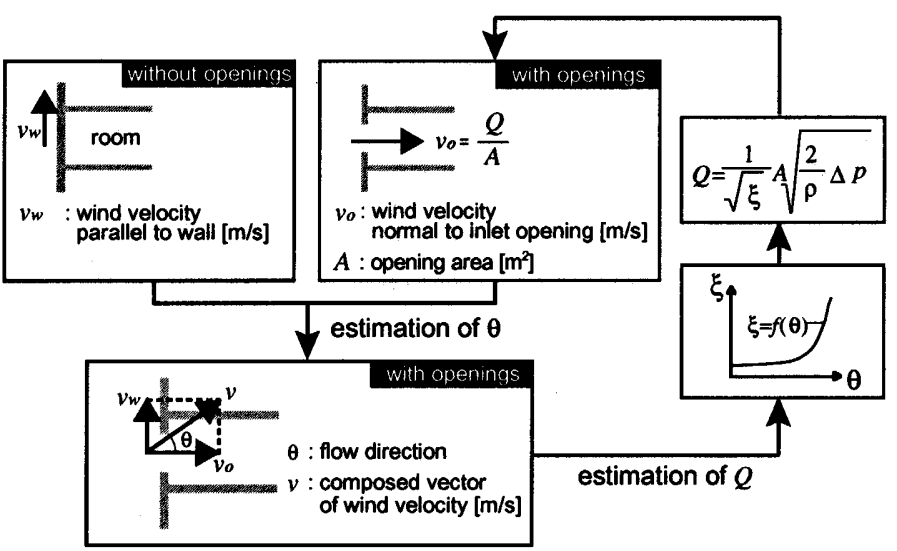

Fig. 3 Vector composition and iteration procedure for calculation of inflow direction

to understand.

Another important point, this method describes $\xi$ as the function of inflow direction as shown in Figure 3. This relation was led by authors' previous measurement using the large chamber in the calm flow field ${ }^{11)}{ }^{12}$. The cubic chamber of which one side is $900 \mathrm{~mm}$ was used and the room model with opening was inserted at the side of the cube as shown in Figure 4. The air in the cube was sucked by a mechanical fan. The relationship between the airflow rate and the total pressure difference between inside and outside of the cube were measured at the various flow rates. The inlet wind direction was controlled by means of a guided duct in front of the openings. 
As a result, the pressure loss coefficient of the room $\xi$ at the various inlet wind direction was calculated by general orifice equation. Table 1 and Figure 5 show the experimental conditions, two angles for the plane parallel to opening (azimuth) and five inlet wind directions were used. That is to

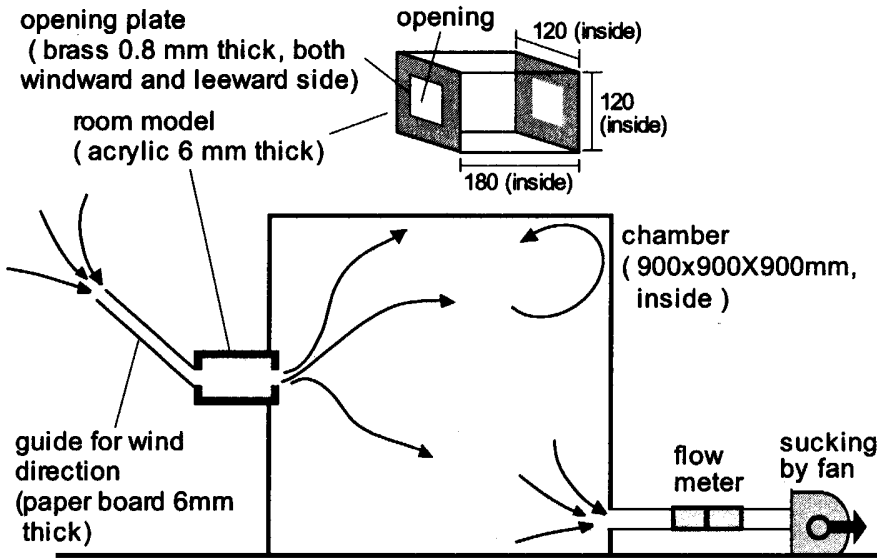

Fig. 4 Chamber method using room model with two openings.

Table 1 Experimental condition for chamber method

\begin{tabular}{c|l}
\hline azimuth $\alpha$ [deg.] & 0,45 \\
\hline $\begin{array}{c}\text { inlet wind direction } \\
\theta \text { [deg.] }\end{array}$ & $0,22.5,45,67.5,80$ \\
\hline
\end{tabular}

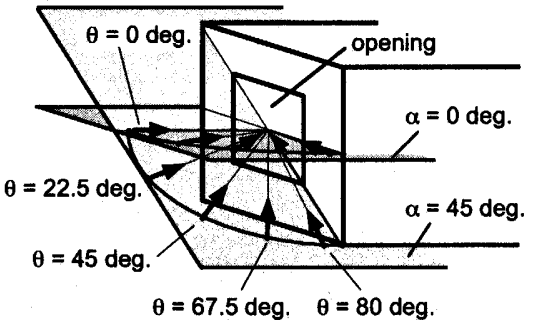

Fig. 5 Setting of azimuth and inlet direction for chamber method (see Table 1)

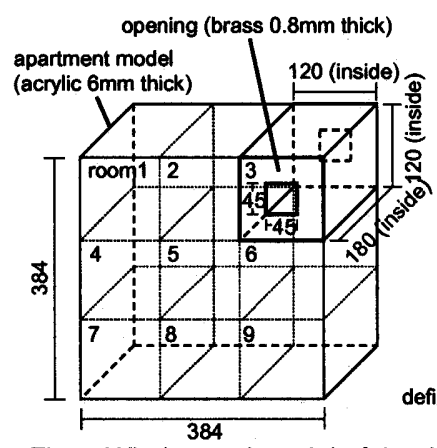

Fig. 7 Wind tunnel model of the three-storied apartment building with large opened room.

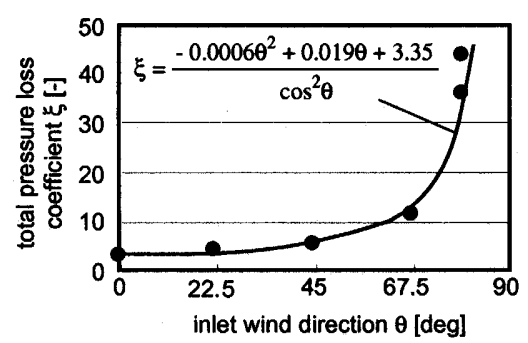

Fig. 6 Relationship between inlet wind direction $\theta$ and total pressure loss coefficient $\xi$.

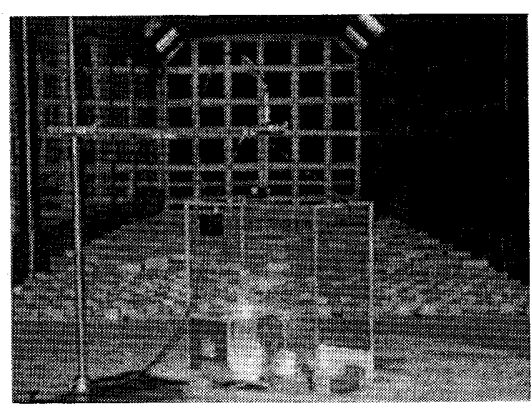

Fig. 8 Wind tunnel setup.

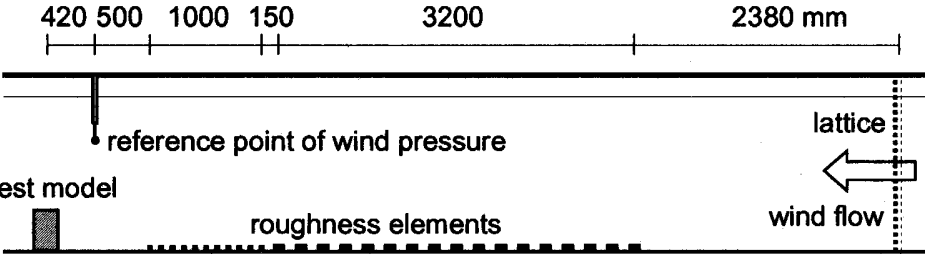

Fig. 9 Wind tunnel geometry. say, this is the limit of application and the validation of this method when the following relationship is used. The relationship between inlet wind direction and total pressure loss coefficient by the previous measurement and its regression functions are shown in Figure 6. In this relationship, the pressure loss coefficient of the guide for wind direction in Figure 4 is not included and the values of inlet pressure loss coefficient without the guide are compensated. For different situation of the opening and room location of this measurement, for instance, (1) the opening sizes are different, (2) opening location is shifted or (3) openings are not located at the opposite wall, authors already have obtained the relation between inlet wind direction and total pressure loss coefficient ${ }^{17}$.

\section{Wind tunnel test}

The wind tunnel tests using a three-storied apartment building model with a room were conducted to investigate the inflow direction and the flow rate at the opening. The room with the opening can be set at the different nine positions. Figure 7 and Figure 8 show the apartment model and the setup situation on the floor of the wind tunnel of which approaching flow is the atmospheric boundary layer of $1 / 5$ power low. Figure 9 shows the wind tunnel geometry and the approaching wind profile is shown in Figure 10. The large-scale turbulence is generated by the lattice, and the roughness elements on the tunnel floor make the small-scale turbulence and the boundary layer. The reference external wind velocity is $10 \mathrm{~m} / \mathrm{s}$ at $1000 \mathrm{~mm}$ height from the tunnel floor. The combination of the room positions and the external wind directions make various inflow directions at the inlet opening.

The wind velocities parallel to the wall in front of the position where the openings locates were measured by constant-temperature hot-wire anemometer during 30 seconds with its sampling frequency of $250 \mathrm{~Hz}$ as shown in Figure 11. The measuring points were set at the $5 \mathrm{~mm}$ in front of the wall. It was checked that this points locates outside the boundary layer of the wall by preliminary velocity measurements except for the case that the measuring position locates inside the wake or the

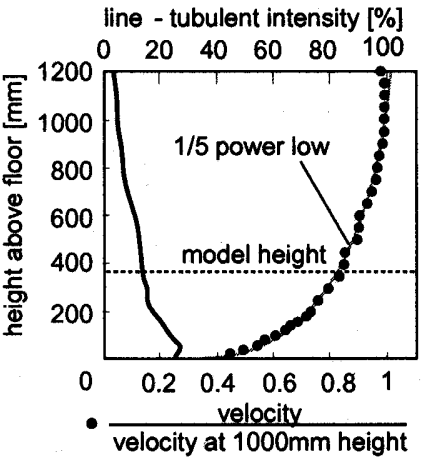

Fig. 10 Approaching wind profiles. 


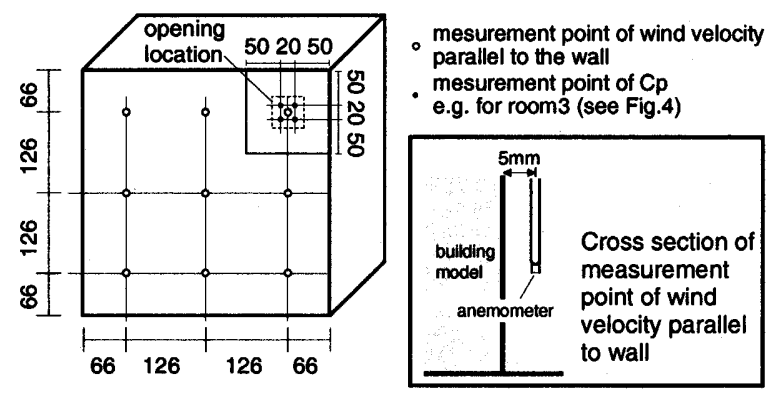

Fig. 11 Measurement points.

separation area when the external wind direction is large.

$C \mathrm{p}$ values were obtained by the measurement of the wind pressure at four small hall of $\phi 1 \mathrm{~mm}$ where the opening locates as shown in Figure 11. The wind pressures were measured by manometer during 30 seconds with its sampling frequency of $100 \mathrm{~Hz}$ and those averaged values at each opening position were calculated. The dynamic pressure at the building height (384 $\mathrm{mm}$ ) is calculated from the value at $1000 \mathrm{~mm}$ above wind tunnel floor by pitot tube as shown in Figure 9 as the reference value for $C$ p. It should be noted that the measurements of the wind velocities parallel to the wall and $C p$ values were conducted under the situation that openings were closed.

The inflow direction and wind velocity at the inlet openings were measured by constant-temperature hot-film anemometer with split film probe during 30 seconds with its sampling frequency of $100 \mathrm{~Hz}$. This anemometer can measure the wind velocity and wind direction at the same time. This anemometer has 'split line' between two films and the wind direction can be judged by the comparison of the output signal from these two films. The calibration for wind direction and wind velocity should be carried out in advance for obtaining the two components of the wind vector on a certain plane. However, to obtain the nominal vector of the opening as shown in Figure 12, velocity vectors on the vertical and horizontal plane should be measured and these vectors compose three dimensional vector. Therefore two different setups of probe are needed (see Figure 13). Figure 14 shows the measurement accuracy of anemometer for the wind direction. In the case that the wind direction exceeds +60 and -60 degree, the accuracy decreases and some impossible cases of measurement will occur in a certain wind velocity condition. Therefore the reliance of the data when the inflow direction exceeds 60 degree is not high but data is presented as information in the following discussions.

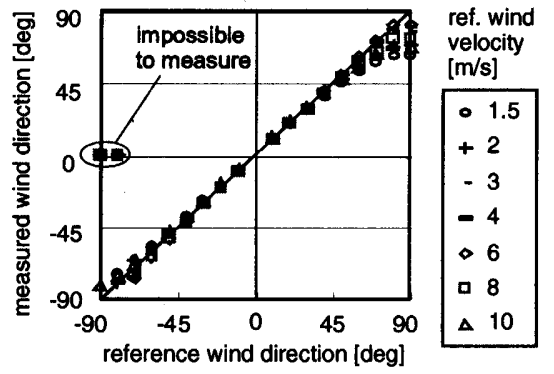

Fig. 14 Measurement accuracy of anemometer

As the purpose of this research focuses the validation of the proposed calculation method, the experimental parameters were limited. Nine room positions and five external wind directions of $0,22.5,45,67.5$ and 80 degree were selected as shown in Table 2 .

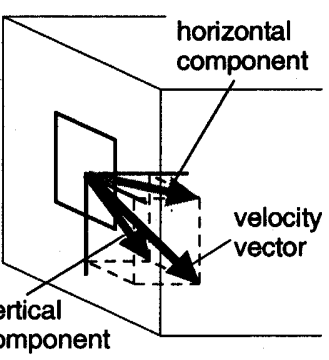

Fig. 12 Velocity vector

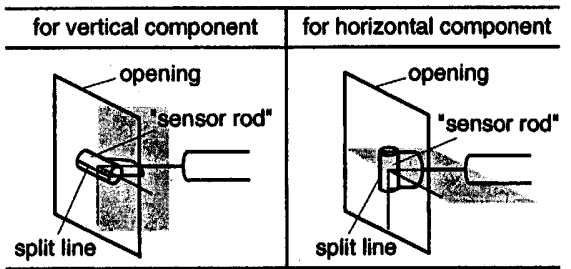

Fig. 13 Anemometer setup

Table 2 Experimental condition (see Fig. 7)

\begin{tabular}{|l|l|}
\hline Room number & $1,2,3,4,5,6,7,8,9$ \\
\hline $\begin{array}{l}\text { External wind direction } \\
\text { [degree] }\end{array}$ & $0,22.5,45,67.5,80$ \\
\hline
\end{tabular}

\section{Wind velocities parallel to the wall and $\mathrm{Cp}$ values}

Figure 15 shows the measurement results of the wind velocity parallel to the wall. The reference wind velocity for the dimensionless velocity is set at the building height $(384 \mathrm{~mm})$. At almost all positions, the increment of the external wind directions leads to the increment of the wind velocities. This can be explained by the acceleration of the wind velocity according to the increment of the distance from the stagnation point of the building. At room 3 , 6 and 9, lower wind velocities are shown when the external wind direction of 22.5 degree. The reason is that these rooms locate at the windward position and expect to be near the stagnation area when the wind direction. This is the same tendency at room 2,5 and 8 at the wind direction of 0 degree. In case that the external wind direction is 80 degree, the external flow is separated by the sidewall of the building and the measuring points locate inside the wake so the wind velocity decreases.

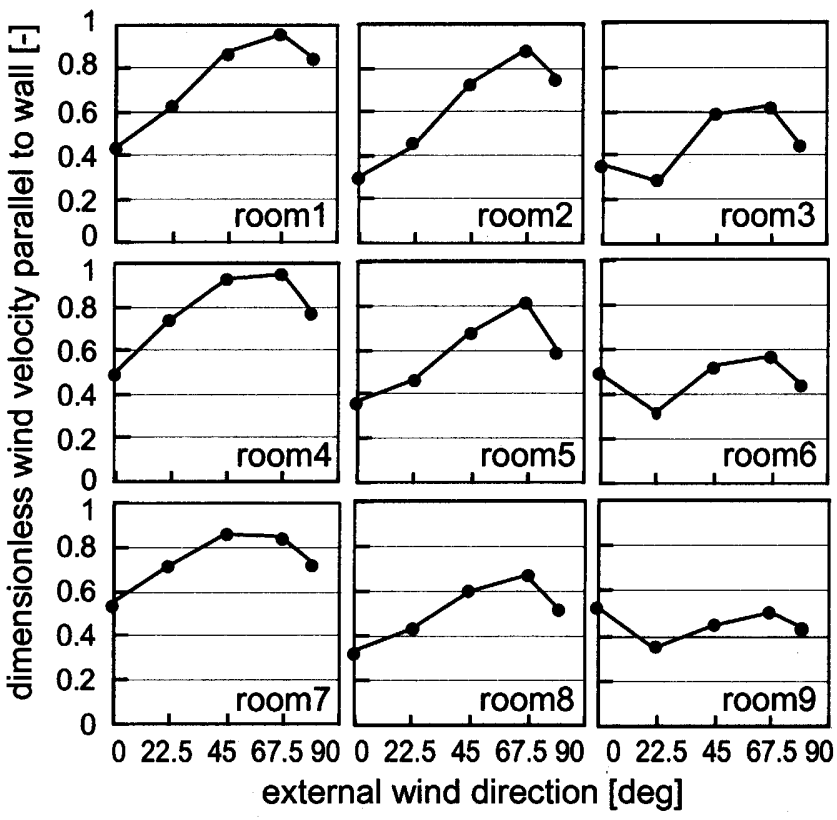

Fig. 15 Relationship between external wind direction and wind velocity parallel to wall

Figure 16 shows the difference of wind pressure coefficient between windward and leeward opening position ( $\triangle C p$ ). These results seem to be the reverse curve to wind velocity parallel to the wall (Fig. 14) in almost all 
cases. This can be understood from the viewpoint that the Bernouli's theory along the wall was realized.

These velocities and $\Delta C p$ values will be used as the input of the proposed calculation method.

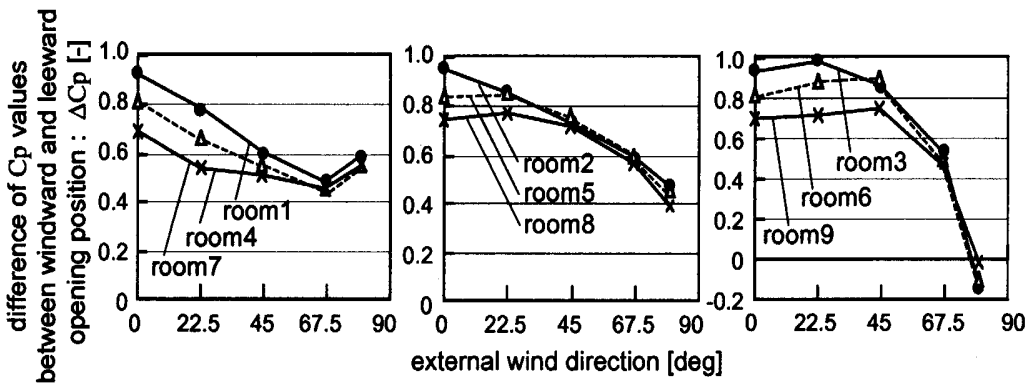

Fig. 16 Relationship between external wind direction and difference of $C p$ values

\section{Inflow direction at the openings}

Figure 17 and 18 show the measured results of the inflow vector at the opening. In this measurement, the building was not sealed and the room opening was opened. Though these figures show the results of nine rooms in one figure, it should be noted that these were measured separately and the experiments were made to know the inflow direction in the case that only one room is set in the building. In some cases, the vectors were not drawn due to the low accuracy of the anemometer.

These vectors show that the inflow direction at the opening is not normal to the opening. Only if the opening locates at the stagnation point of the building, the inflow direction is expected to be normal to the opening. In case that the external wind directior is 80 degrees, openings seem to be inside the wake or separation area of the building, so the velocities became small and the inlet direction came close to the normal to the opening. As for the same wind direction ( 80 degrees), values of $\Delta C p$ of room 3,6 and 9 show negative values or almost zero in Figure 16, so the outflow can occur at some positions inside the opening or there can be the measurement errors of $\Delta C \mathrm{p}$. From the vectors on a vertical plane, it is suggested that the vertical stagnation point of the building locates between the second floor and the third floor at every external wind directions. As for the horizontal stagnation points, it is dependent upon the external wind direction.

These figures were reasonable from the viewpoint of the flow around and along the building.

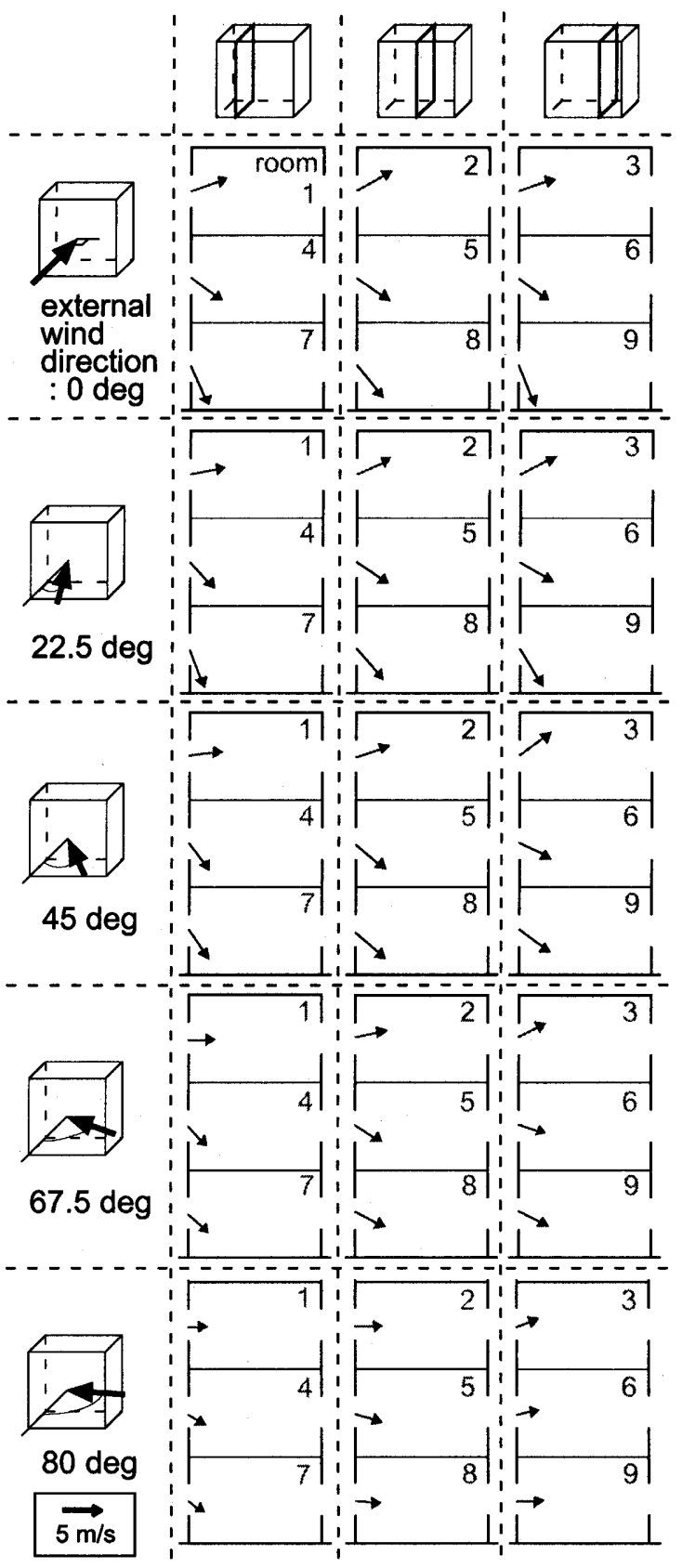

Fig. 17 Inflow vectors on vertical plane at openings

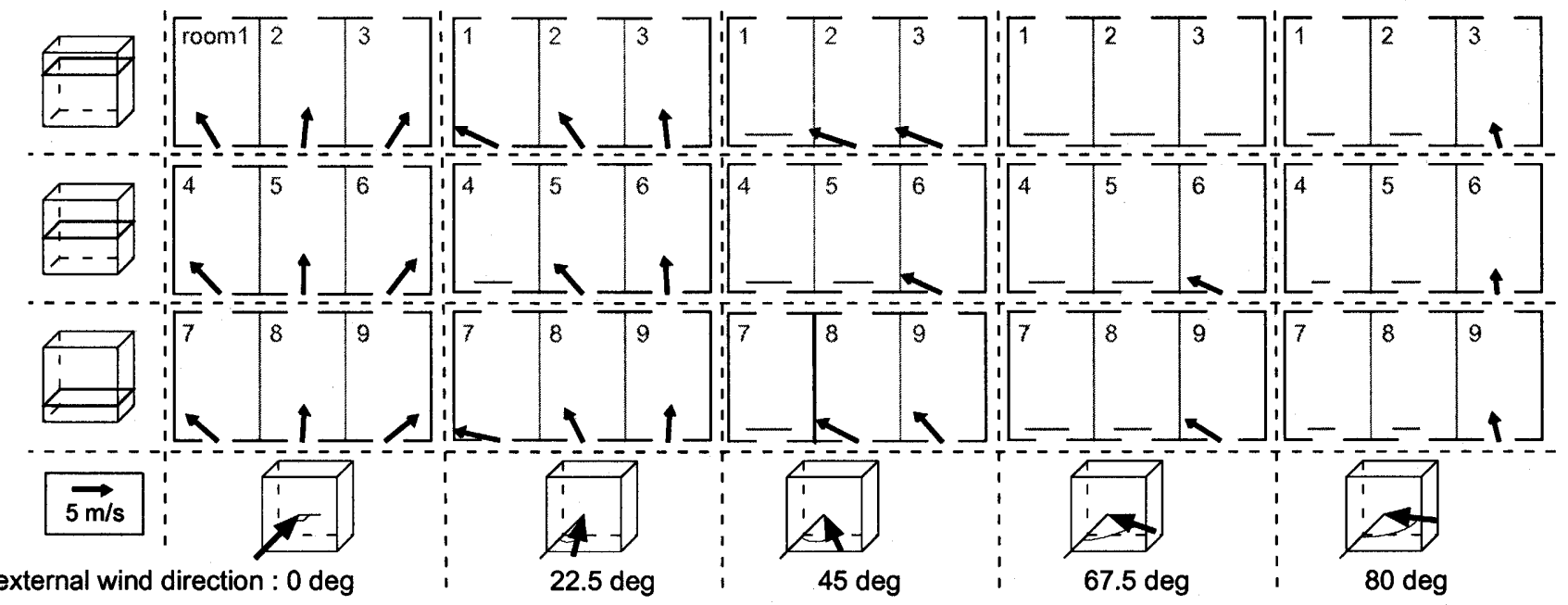

Fig. 18 Inflow vectors on horizontal plane at openings 


\section{Comparison with calculated results using the proposed method}

The prediction of inflow direction as mentioned above were conducted using measured the wind velocities parallel to the wall and $C p$ values. Figure 19 shows the way to obtain the normal vector to opening from the vertical and horizontal vectors as shown in Figure 17 and 18 that should be compared with predicted inflow directions.

Figure 20 shows the measured inflow direction (see Figure 17 and 18) and calculated one. Plots show the measurement direction and the lines are the calculated one. There are some lacks in the measurement results.

Though the errors are very large in case that the external wind direction is $\mathbf{8 0}$ degree, they are in good agreement. 80 degree of the wind direction means that the openings locates inside the wake or separation area, so the different mechanism of the ventilation can occur like pulsation or turbulence diffusion. It should be also noted that the reliance of the data when the inflow direction exceeds 60 degree are not high and the accuracy of the measurement decrease unavoidably in case of the low velocity.

This result supports that the proposed calculation method has enough accuracy of the prediction of the inlet wind direction at the opening in the most parts of the external wind directions of from 0 to 45 degree.

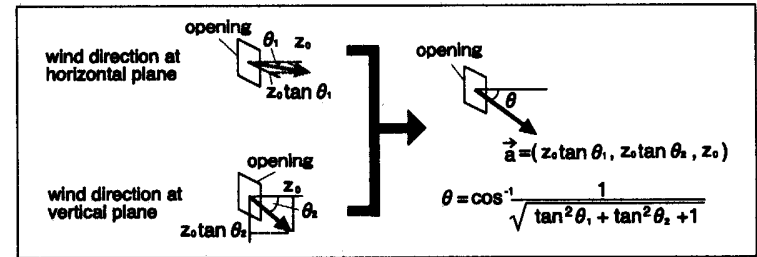

Fig. 19 Calculation of normal vector to opening

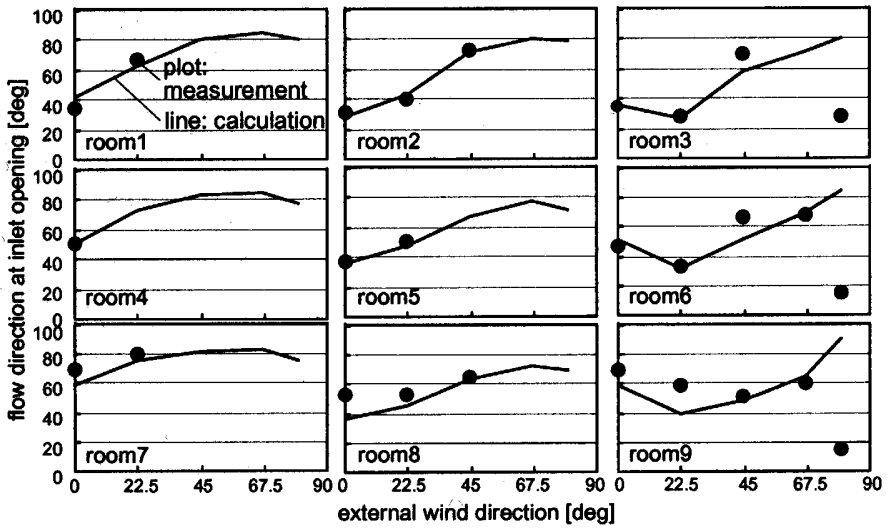

Fig. 20 Comparison between measured inflow direction and calculated one.

\section{Conclusion}

The simultaneous prediction method of inflow direction and airflow rate was proposed and its experimental validation for inflow wind direction was conducted. This method includes the wind velocity parallel to the wall and $C \mathrm{p}$ values systematically. Also the relationship between the inlet wind direction and the total pressure loss coefficient of the room are needed.

In general flow conditions that means the openings do not locate inside the wake or the separation area, the proposed method is concluded to be valid. However the problem of the experimental accuracy when the inflow direction is large remains. Future studies will focus on the reasonable prediction of the wind velocity parallel to the wall and $C \mathrm{p}$ values.

\section{Acknowledgement}

The part of this research is supported by TOSTEM Foundation for Construction Materials Industry Promotion, 2001- No.01-7. Authors would like to thank Mr. Kazutaka Igarashi, Mr. Jun Furukawa, Ms. Keiko Ochi and Mr. Ken-icihro Nagai for their supports in carrying out the experiments.

\section{References}

1) M. Ishihara. Building Ventilation Design. Asakura Publisher, pp.213-214, 1963

2) N. Kiyota and T. Sekine. Experimental Study on Pressure Loss at the Opening of Wall Surface -Part2. J. Architecture, Planning and Environmental Engineering (Transaction of AIJ), No.398, pp.565-568, 1989

3) T. Kurabuchi and M. Kamata. Numerical Simulation of the Combined Internal and External Airflow for Cross Ventilation of Buildings by means of the Multi-mesh Method. J. Architecture, Planning and Environmental Engineering (Transaction of AIJ), No.426, pp.1-11, 1991

4) S. Murakami, S. Kato, S. Akabayashi, K. Mizutani and Y Kim. Wind Tunnel Test on Velocity-pressure Field of Cross-ventilation with Open Windows, ASHRAE Transactions, 97, Part.1, pp.525-538, 1991

5) P. He, T. Katayama, T. Hayashi and J. Tsutsumi. Basic Examination on Cross-ventilation Rates of Single Unit Models by Numerical Simulation, J. Architecture, Planning and Environmental Engineering (Transaction of AIJ), No.474, pp.47-55, 1995

6) P. Heiselberg (ed.). Principle of Hybrid Ventilation. IEA-ECBCS Annex 35 Final Report, Aalborg University, Denmark, 2002

7) P. Heiselberg (ed.). HybVent -Hybrid Ventilation Special Edition. The International Journal of Ventilation, Vol.1, Special Edition, 2003

8) M. Sandberg. Airflow through Large Openings - Catchment Problem? In Proc. Roomvent2002, Copenhagen, Denmark, pp.541-544, 2002

9) T. Sawachi. Detailed Observation of Cross Ventilation and Airflow through Large Openings by Full Scale Building Model in Wind Tunnel. In: Proc. Roomvent2002. Copenhagen Denmark, pp.565-568, 2002

10) T. Kurabuchi, M. Ohba, Y. Fugo and T. Endoh. Local Similarity Model of Cross-Ventilation -Part1. In: Proc. Roomvent2002. Copenhagen Denmark, pp.613-616, 2002

11) H. Kotani, T. Yamanaka and J. Furukawa. Cross Ventilation Rate of Building with Arranged in Series -Part3. In: Proc. Annual Meeting of AIJ, D2, pp.553-554, 2000

12) K. Ochi, T. Yamanaka and H. Kotani. Cross Ventilation Rate of Building with Arranged in Series -Part5\&6. In: Proc. Annual Meeting of AIJ, D2, pp.635-638, 2001

13) JJ. True, M. Sandberg, P. Heiselberg and PV. Nielsen. Wind Driven CrossFlow Analyzed as Catchment Problem and as a Pressure Driven flow. The International Journal of Ventilation, Vol.1, Special Edition, pp.89-101, 2003

14) T. Kurabuchi and M. Ohba. Local Dynamic Similarity Model of CrossVentilation -Part1. The International Journal of Ventilation, Vol.2, No.4, pp.371-382, 2004

15) T. Yamanaka, M. Narasaki, T. Daikoku and H. Kotani. Study on the Simplified Calculation Model for Prediction of the Wind Pressure Coefficient on Building -Part5. In: Proc. Annual Meeting of AIJ, D, pp.561-562, 1991

16) T. Yamanaka, M. Narasaki and $K$. Iwamoto. Ventilation of an Enclosure Caused by Turbulent Wind -Part27. In: Proc. Annual Meeting of AIJ, D, pp.593-594, 1992

17) T. Nakamori, T. Yamanaka and H. Kotani. Cross Ventilation Rate of Building with Arranged in Series -Part9. In: Proc. Annual Meeting of AIJ Kinki Branch, Environmental Engineering, pp.301-304, 2003 


\section{和文要約}

\section{1. はじめに}

建物の通風量予測に関しては、古くから日本の研究者によって研 究がなされ、また近年では IEA-ECBCS Annex 35 の研究グループ により、精力的に研究が行われている。

一般に大開口での通風時に、室全体の圧力損失係数 $\xi$ は、開口単

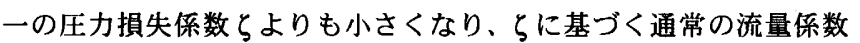
$\left(\mathrm{C}_{\mathrm{D}}\right)$ 值を用いた通風量計算は通風量を過小評価する。これが圧力 損失係数に関する研究が対象としている 1 点目である、速度圧が解 消しない事による圧力損失係数の隇少に関する問題であり、これは 古くから石原 ${ }^{11}$ が「干渉係数」として扱ったことで知られる。2 点 目は、圧力損失係数（流量係数）が開口における流入角の增大によっ て增加（流量係数は隇少）する問題であり、これは逆に通風量を過

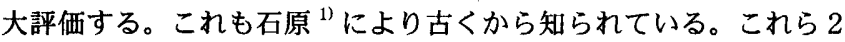
点の問題は多くの研究者によって指摘され、詳細なレビューも倉㴊・ 大場 ${ }^{14)}$ により行われている。しかしながら、現時点で簡易かつ合理 的な通風量予測法は確立されているとは言い難く、本研究はその提 案を行うものである。同様の考え方に、倉㴊ら ${ }^{10)}$ が提案する「局所 相似モデル」があるが、これは圧力をべースとした記述であり、本 研究はより簡易で分かりやすい予測法を提案するものである。本研 究は，これまで筆者らが集合住宅の形状を持つ建物を主対象として 行ってきた, 室全体の圧力損失係数、風圧係数、壁面近傍流の予測 法と組み合わせることにより、今後、通風量予測法の確立を目指す ものであるが、本論は，それらを入力した予測法の根幹をなす流入 角予測法自体の提案と精度検証を行うものである.

\section{2. 流入角と通風量の同時予測法}

図 2、図 3 に示す通り、筆者らがこれまでの研究 ${ }^{11}{ }^{12}$ により得た 流入角之室全体の圧力損失係数乡に関する回帰式（図6。これは、 図 4、図 5、表 1 に示すチャンバー法により得たものである) を用 いて、流入角と通風量を収束計算により予測する手法を提案する。 本手法の新たなるコンセプトは、開口が閉じた状態で開口前面で壁 面に沿って流れる気流（壁面近傍流）の風速と、推定された流入角 度から回帰式を用いて得られる圧力損失係数 て換気の式で算出される開口に垂直な成分風速の、2つの風速成分 のベクトル合成を用いることにある。この手法は収束計算を用いる ものの比較的簡易で、実用に供することを目的としており、また壁 面近傍流という理解しやすい現象を用いることに特徵がある。

\section{3. 風洞実験}

開口を持つ室を 9 箅所に配置できる 3 階建集合住宅を想定した建 物模型（図 7, 図 8）を用いて、1/5 ベき乗則の接地境界層内での 風洞実験（図 9 ，図 10）により、本手法の妥当性を検証する。室の 配置と外部風向を変化することにより開口で種々の流入角を得る。

壁面近傍流は、開口を閉じた状態で開口位置前面 $5 \mathrm{~mm}$ で熱線風 速計により測定した（図 11）。なお、予備実験により、建物の剥離 域にならない限り、測定点は壁面境界層の外に位置していることを 確認している。風圧係数は、開口を閉じた状態で、開口が位置する 壁面内での 4 点の測定値の平均値を用いた（図 11）。
流入開ロでの流入角は、スプリットフィルムプローブを有する熱 膜風速計により測定した。本プローブは風速と風向を同時測定でき るものの、図 12 に示す開口の法線方向のベクトルを算出するため には、水平成分と鈶直成分の 2 成分を測定する必要があるため、図 13 に示す通り、2 通りのプローブのアプローチを行った。図 14 に 示す通り、風向の測定精度は土 $60^{\circ}$ を超えた場合に低下が見られ、 風速によっては風向が測定不能となる場合もある。

\section{4. 壁面近傍流の風速および風圧係数}

図 15 に、壁面近傍流の風速測定結果を示す。多くの室位置にお いて、外部風向の増加は風速の增加を招き、これは建物よどみ点か らの距離が遠くなるに従い、壁面近傍流が発達・加速することから 説明できる。外部風向が $80^{\circ}$ の場合、測定点が建物側壁での剥離域 に入るために、風速は低下する。

図 16 に室の風上側と風下側の開口位置での風圧係数差を示す。 図 15 に示した壁面近傍流の傾向と逆の傾向が見られる。これは、 壁面に沿った流れにおいて、ベルヌーイの定理が成立しているであ ろう事から説明できる。

これら壁面近傍流の風速と風圧係数差は本予測手法での入力とな るものである。

\section{5. 開口における流入角}

図 14、図 15 に、開口が開いた状態での流入ベクトルの測定結果 を示す。図では 9 室の流入ベクトルを同時に描いているものの、測 定は各室での開口を順に開けて行ったものであり、またいくつかの 条件では、風速計の精度が低いために測定値が得られていない。

外部風向が $80^{\circ}$ の場合、開口は建物の剥離域に入るために、風速 は小さく、開口に垂直に近い角度で流入している様子が伺える。鉆 直面での流入ベクトルからは、建物のよどみ点が 2 階と 3 階の間に あることが推察され、また水平面での流入ベクトルから水平方向の よどみ点は外部風向に依存することが分かる。

\section{6. 提案手法を用いた計算との比較}

提案する手法により、壁面近傍流の風速と風圧係数の測定値を用 いて、流入角の予測を行った。比較対象となる流入角の測定値は、 図 17 と図 18 で示した測定值から図 19 に示す手法で算出した。

外部風向 $80^{\circ}$ での誤差は大きいものの、その他の外部風向では良 い一致が見られる。外部風向 $80^{\circ}$ は剥離域内にあり、脈動や乱流拡 散などの異なるメカニズムによって通風が行われている可能性が高 い。本結果により、流入角度の大きい条件においては測定精度の問 題が残るものの、本研究で提案する手法が大多数の外部風向におい て有効であることが確認できた。

\section{7. 結論}

流入角と通風量の同時予測法を提案し、流入角の測定実験により 精度の検証を行った。本手法は、壁面近傍流の風速と風圧係数を組 み込み、また流入風向と室全体の圧力損失係数との関係を必要とす る手法である。流入開口が建物の剥離域に入ることのない多くの条 件において、本手法は有効であることが確認された。壁面近傍流の 風速と風圧係数の合理的な予測が今後の課題である。 